\title{
Nonchemical, Cultural Management Strategies to Suppress Phytophthora Root Rot in Northern Highbush Blueberry
}

\author{
John R. Yeo ${ }^{1}$ \\ Department of Crop and Soil Science, 3017 Agricultural \& Life Sciences \\ Building, Oregon State University, Corvallis, OR 97331 \\ Jerry E. Weiland ${ }^{2}$ \\ U.S. Department of Agriculture, Agricultural Research Service, Horticultural \\ Crops Research Unit, 3420 NW Orchard Avenue, Corvallis, OR 97330
}

\author{
Dan M. Sullivan \\ Department of Crop and Soil Science, 3017 Agricultural \& Life Sciences \\ Building, Oregon State University, Corvallis, OR 97331
}

\author{
David R. Bryla \\ U.S. Department of Agriculture, Agricultural Research Service, Horticultural \\ Crops Research Unit, 3420 NW Orchard Avenue, Corvallis, OR 97330
}

Additional index words. Vaccinium corymbosum, Phytophthora cinnamomi, drip irrigation, gypsum, mulch, soilborne plant pathogens

\begin{abstract}
Phytophthora cinnamomi Rands causes root rot of northern highbush blueberry (Vaccinium corymbosum L.), which decreases plant growth, yield, and profitability for growers. Fungicides are available to suppress the disease, but are prone to development of resistance in target pathogens and cannot be used in certified organic production systems. Alternative, nonchemical, cultural management strategies were evaluated to reduce phytophthora root rot in a field infested with $P$. cinnamomi. The field was planted with 'Draper' blueberry, which is highly susceptible to the pathogen. The soil was either amended with gypsum or not before planting, and the plants were irrigated using narrow (adjacent to plant crown) or widely spaced $(20 \mathrm{~cm}$ on either side of the plant crown) drip lines and mulched with douglas fir sawdust or black, woven geotextile fabric (weed mat). A fungicide control treatment was also included in the study and consisted of applying two conventional fungicides, mefenoxam and fosetyl-Al, to plants irrigated with narrow drip lines and mulched with sawdust. Initially, root infection by $P$. cinnamomi was lower with the combination of gypsum, wide drip lines, and sawdust mulch than with any other treatment, except the fungicide control. The soil under weed mat accumulated more heat units than under sawdust and resulted in faster hyphal growth by the pathogen. However, plant growth was similar in both mulch types. The effects of drip line placement and gypsum, on the other hand, were interactive, and plants grown with a combination of wide drip lines and gypsum produced the greatest amount of biomass among the cultural treatments. Narrow drip lines negated the disease-suppressive effects of gypsum by moving zoospore-inhibiting $\mathrm{Ca}^{2+}$ away from the plant root zone, and also resulted in wetter soil near the crown of the plants, which likely promoted zoospore discharge and root infection. However, wide drip lines resulted in $\mathbf{N}$ deficiency symptoms during the first year after planting and, therefore, resulted in less plant growth than the fungicide control. Thus, if $\mathbf{N}$ is managed properly, this study suggests that concerted use of gypsum and wide drip lines can help suppress phytophthora root rot in northern highbush blueberry and increase production in field soils where the pathogen is present.
\end{abstract}

\footnotetext{
Received for publication 6 Oct. 2016. Accepted for publication 2 Apr. 2017.

Financial support was provided by the Oregon Blueberry Commission, the Oregon State University Agricultural Research Foundation, and industry contributors. Mention of trademark, proprietary product, or vendor does not constitute a guarantee or warranty of the product by Oregon State University or the U.S. Department of Agriculture and does not imply its approval to the exclusion of other products or vendors that also may be suitable.

${ }^{1}$ Former graduate student.

${ }^{2}$ Corresponding author. E-mail: jerry.weiland@ars. usda.gov.
}

Phytophthora cinnamomi Rands is a soilborne pathogen that causes root rot in $>900$ plant species worldwide, including northern highbush blueberry (Zentmyer, 1980). Currently, there are two groups of fungicides (phenylamides and phosphonates) registered for root rot control in blueberry, including mefenoxam and fosetyl-Al (Brannen et al., 2009). Unfortunately, the risk of developing fungicide resistance is very high in Phytophthora species, especially to mefenoxam $(\mathrm{Hu}$ et al., 2010). In addition, organic blueberry production is increasing rapidly, but neither of these chemicals is certified for use on organic crops (DeVetter et al., 2015). Preplant soil fumigation is also an option for managing root rot. However, it is expensive, not widely used in the industry, and there is little evidence for its effectiveness against this disease in blueberry production systems. The risk of crop loss from $P$. cinnamomi may increase substantially without fungicides; therefore, disease-suppressive cultural practices are needed for both conventional and organic blueberry systems.

Organic mulches (e.g., sawdust or bark) have been shown to suppress soil populations of $P$. cinnamomi in eucalyptus (Eucalyptus sp. L'Hér.), fraser fir [Abies fraseri (Pursh) Poir.], and avocado (Persea americana Mill.) plantings (Downer et al., 2001; Menge et al., 1994; Richter et al., 2011a). The cell walls of Phytophthora hyphae are largely composed of glucans, and glucanase activity associated with the microbes in organic mulches may cause hyphal lysis and sporangial abortion (Downer et al., 2001; Richter et al., 2011b). Historically, most blueberry fields were mulched with sawdust or bark chips (Strik and Yarborough, 2005). However, many new fields are mulched with geotextile fabrics, often referred to as "weed mat." Weed mat is more economical for weed control than sawdust, particularly in organic systems, and the use of it may result in greater plant growth and yield in blueberry (Julian et al., 2012; Larco et al., 2013). Most growers use black weed mat, which increases soil temperature during sunny days, especially when there is little shade under the canopy such as early in the season and in new plantings (Larco, 2010). Root infection by P. cinnamomi has been shown to be more severe when soil temperature exceeds $25^{\circ} \mathrm{C}$ (Erwin and Ribeiro, 1996). Therefore, it is possible that weed mat may increase the incidence of phytophthora root rot in blueberry.

The zoospore infection cycle of $P$. cinnamomi requires nearly saturated soil moisture conditions (de Silva et al., 1999). Consequently, infection is readily affected by heavy rain or irrigation and is often greater when plants are irrigated by drip irrigation than by sprinklers or microsprinklers, which results in increased soil water content near the plant crown (Bryla and Linderman, 2007). Whereas most blueberry fields were historically irrigated by sprinklers, many are now irrigated by drip because of concerns for food safety and efforts to increase water use efficiency (Bryla et al., 2011). Many blueberry growers use two lines of drip tubing per row, with one line placed on either side of the plant (Ehret et al., 2012). The drip lines are usually placed near the plant crown during the first year or two after planting and are later moved $15-20 \mathrm{~cm}$ from the crown, once the root system develops (Bryla and Strik, 2015). However, given the propensity for developing root rot in wetter soils, Bryla and Linderman (2007) suggested that blueberry plants might benefit from a wider drip line spacing immediately after planting, 
particularly if the soil is already infested with P. cinnamomi.

Soil amendment with calcium may also suppress phytophthora root rot (Menge et al., 1994; Messenger et al., 2000a; Pinkerton et al., 2009). A high level of calcium in the soil inhibits zoospore motility of the pathogen and thereby disrupts the infection process (Messenger et al., 2000b). Greenhouse assays suggested that gypsum may be useful for reducing phytophthora root rot in northern highbush blueberry (Yeo, 2014). Gypsum provides more soluble $\mathrm{Ca}^{2+}$ than carbonate sources such as lime and does not increase soil $\mathrm{pH}$ appreciably (Shainberg et al., 1989). High soil pH is deleterious to many ericaceous plant species, including northern highbush blueberry, which is adapted to soil $\mathrm{pH}$ in the range of 4.5-5.5 (Hart et al., 2006).

The objective of the present study was to evaluate the effects of mulch type, drip line placement, and gypsum on phytophthora root rot in northern highbush blueberry. The study was carried out in a new planting, as young plants are usually the most susceptible to root rot (Bryla and Linderman, 2007).

\section{Materials and Methods}

Study site. The study was located at the Oregon State University Lewis Brown Horticultural Research Farm in Corvallis, OR (lat. $44^{\circ} 33^{\prime} 10^{\prime \prime} \mathrm{N}$, long. $123^{\circ} 13^{\prime} 9^{\prime \prime} \mathrm{W}, 68 \mathrm{~m}$ elevation). Soil at the site is classified as a Malabon silty clay loam (fine, mixed, mesic Pachic Ultic Argixeroll). A soil test in Feb. 2012 indicated that the $\mathrm{pH}$ of the soil was 5.4, the cation exchange capacity was 24.4 $\mathrm{cmol} \cdot \mathrm{kg}^{-1}$, and Bray-P was $23 \mathrm{ppm}$ (Kuo Testing Laboratories, Othello, WA).

Previously, the site was planted with 'Duke' northern highbush blueberry in 2004. The planting was removed in 2010 because of severe problems with phytophthora root rot (Bryla, 2006). After the planting was removed, the field was seeded with a cover crop mix of fava bean (Vicia faba L.), vetch (Vicia sativa L.), oat (Avena sativa L.), and clover (Trifolium pretense L.) in the fall of 2011. The cover crop was killed with glyphosate (2.24 kg a.i./ha) in Apr. 2012 and tilled into the soil using a 182-cm-wide power spader (Tortella, Ortona, Italy) to a depth of $30 \mathrm{~cm}$ on 9 May 2012. Douglas fir (Pseudotsuga menziesii Franco) sawdust (Lane Forest Products, Eugene, OR), aged for 1 year, was spread out in a 2.5 -cm-thick layer across the field and incorporated with a 127cm-wide rototiller (Howard Selectatilth, Sorø, Denmark) to a depth of $15 \mathrm{~cm}$. Eight raised beds were formed $0.3-\mathrm{m}$ high and 1.0-m wide using a tractor-drawn bed shaper (Ernst Irrigation, St. Paul, OR). The raised beds were $45-\mathrm{m}$ long $\left(28^{\circ} \mathrm{N}-208^{\circ} \mathrm{S}\right.$ orientation) and centered $3.0-\mathrm{m}$ apart. The areas between the raised beds were seeded with annual ryegrass (Lolium multiflorum Lam.), which was mowed regularly after establishment and went dormant in the summer.
To enhance uniform disease pressure, additional $P$. cinnamomi inoculum was incorporated into the soil in May 2012 after the beds were shaped. Inoculum was produced in fungal spawn bags with filter patches (Fungi Perfecti, Sheldon, WA). Twenty-seven bags were filled with $3 \mathrm{~L}$ of medium-grade vermiculite and $1.5 \mathrm{~L}$ of $\mathrm{V}-8$ juice broth consisting of $10 \%$ V-8 juice (Campbell Soup Co., Camden, NJ) by volume and amended with $2 \mathrm{~g} \cdot \mathrm{L}^{-1} \mathrm{CaCO}_{3}$. The bags were autoclaved for $55 \mathrm{~min}$. After cooling, a 100-mmdiameter petri plate filled with potato dextrose agar (PDA) and fully colonized with a 10-d-old isolate of $P$. cinnamomi was sliced into 100 pieces and added to each bag. The isolate was obtained in 2010 from a 'Draper' blueberry plant infected naturally in a field located in Corvallis, OR (Vargas et al., 2015) and was successfully used in previous experiments to cause root rot (Yeo et al., 2016). Each bag was incubated in the dark at $20{ }^{\circ} \mathrm{C}$ and shaken at 2-week intervals. After 4 weeks, inoculum from all of the bags was homogenized in a cement mixer, and $1.56 \mathrm{~kg}$ of the resulting mixture was spread out in a $30-\mathrm{cm}$-wide band and incorporated $15-\mathrm{cm}$ deep into each planting bed using a front-tine rototiller (Sears and Roebuck, Hoffman Estates, IL). The final density of the inoculum was $2.7 \mathrm{cfu}$ per $\mathrm{cm}^{3}$ of soil.

Treatments and experimental design. Nine treatments (eight cultural treatments and one fungicide control treatment) were applied to the center six beds in the planting on May 2012. The outer two beds in the planting served as nontreated borders. The treatments were arranged in a split-plot design with six replicate blocks (beds). Two mulch types (weed mat and sawdust) were randomly assigned as main plot treatments, and a combination of two drip line spacings (narrow and wide) and two gypsum levels (applied or not) were randomly assigned as subplot treatments (4.6-m long each), for a total of eight cultural treatments (two mulch types $\times$ two drip line spacings $\times$ two gypsum levels). A fungicide treatment (below) was also included in the study and was randomly assigned as a subplot within each of the sawdust main plots.

Gypsum $\left(\mathrm{CaSO}_{4} * 2 \mathrm{H}_{2} \mathrm{O}\right)$ was applied at a rate equivalent to $2.24 \mathrm{t} \cdot \mathrm{ha}^{-1}$. The gypsum was spread out in a 0.3 -m-wide band on the beds and was incorporated $15-\mathrm{cm}$ deep with a narrow front-tine rototiller (Sears and Roebuck, Hoffman Estates, IL). Mulch and drip lines were added to the beds after planting. A line of drip tubing (Toro MicroIrrigation, El Cajon, CA) was installed on each side of the bed and secured either next to (narrow spacing) or $20 \mathrm{~cm}$ (wide spacing) from the plant crown using wire staples. The tubing had $1 \mathrm{~L} \cdot \mathrm{h}^{-1}$ in-line, pressurecompensating drip emitters spaced every $30 \mathrm{~cm}$. Douglas fir sawdust mulch was applied $\approx 8$-cm deep on the beds using a sidedischarge mulch spreader. Black weed mat (Berry Hill Drip Irrigation, Buffalo Junction, VA) was placed on each side of the beds and secured in place with wire staples; two strips were used and overlapped in the center of the bed. Slits were cut and folded under to create $15-\mathrm{cm}$-square openings in the weed mat for each plant.

The fungicide control treatment had no gypsum and was irrigated with narrow drip lines. The plots were treated with mefenoxam (Ridomil Gold SL; Syngenta Crop Protection, Greensboro, NC) and fosetyl-Al (Aliette WDG; Bayer CropScience, Research Triangle Park, NC). Mefenoxam was sprayed on the surface of the beds (45-cm-wide band) shortly after planting in May 2012 and again in May 2013 at a rate of $0.18 \mathrm{~mL} \cdot \mathrm{m}^{-1}$. Fosetyl-Al was sprayed on the fully expanded leaves of the plants in late May each year at a rate of $3.4 \mathrm{~kg} \cdot \mathrm{ha}^{-1}(0.62 \mathrm{~g} / \mathrm{plant})$.

The treatment plots were planted with 'Draper' northern highbush blueberry on 15 May 2012. 'Draper' was selected based on its susceptibility to $P$. cinnamomi (Yeo et al., 2016). The plants were obtained from a commercial nursery (Fall Creek Farm and Nursery, Lowell, OR) as 3-L container stock and spaced 0.76-m apart in the beds. Soil P was low at the site; therefore, triple superphosphate $(0 \mathrm{~N}-45 \mathrm{P}-0 \mathrm{~K})$ was mixed into each planting hole at a rate of $45 \mathrm{~kg} \cdot \mathrm{ha}^{-1} \mathrm{P}$ before planting. Each treatment plot consisted of six contiguous plants, and each bed of treatments had two border plants on each end. The outer beds on either side of the planting were planted on the same date with 'Toro' and 'Reka' northern highbush blueberry.

Irrigation and nitrogen management. The field was initially irrigated daily with handset overhead sprinklers to establish the annual

Table 1. Effect of fungicide treatment on shoot and root dry weight and percent root infection of 'Draper' blueberry grown for 2 years (2012-13) in a field infested with Phytophthora cinnamomi in Corvallis, OR. ${ }^{\mathrm{z}}$

\begin{tabular}{|c|c|c|c|c|c|c|}
\hline \multirow[b]{2}{*}{ Fungicide } & \multicolumn{2}{|c|}{ Shoot dry wt (g/plant) } & \multicolumn{2}{|c|}{ Root dry wt (g/plant) } & \multicolumn{2}{|c|}{ Root infection by $P$. cinnamomi $(\%)^{\mathrm{y}}$} \\
\hline & 2012 & 2013 & 2012 & 2013 & 2012 & 2013 \\
\hline $\mathrm{Yes}^{\mathrm{x}}$ & 175 & 332 & 72 & 130 & 15 & 4 \\
\hline No & 111 & 94 & 34 & 31 & 22 & 10 \\
\hline Significance & $* * *$ & $* * *$ & $* *$ & $* * *$ & NS & NS \\
\hline
\end{tabular}

NS, ${ }^{* *},{ }^{* * *}$ Nonsignificant or significant at $P \leq 0.01$ and 0.001 , respectively.

${ }^{\mathrm{z}}$ The plants were harvested destructively in December of each year. All plants were mulched with sawdust, irrigated with two drip lines located near the plant crown on each side of the bed, and in soil without gypsum amendment.

y Percent of 20 (2012) or 10 (2013) root pieces infected by P. cinnamomi.

${ }^{\mathrm{x}}$ The fungicide applications consisted of mefenoxam $\left(0.18 \mathrm{~mL} \cdot \mathrm{m}^{-1}\right.$, soil spray) and fosetyl-Al $\left(3.4 \mathrm{~kg} \cdot \mathrm{ha}{ }^{-1}\right.$, foliar spray) in May 2012 and 2013. 
ryegrass between the raised beds. Once the grass was established, overhead irrigation was discontinued, and drip irrigation was scheduled four times per week during the growing season using an automated irrigation controller. Irrigation was adjusted weekly based on plant size and reference evapotranspiration obtained from the Corvallis AgriMet agricultural weather station (http://www.usbr.gov/pn/agrimet/), as described previously by Bryla et al. (2011). The weed mat plots were irrigated with $20 \%$ more water than the sawdust plots during the first year after planting to compensate for greater plant water use with weed mat. Water use is initially greater with weed mat because of warmer soil and canopy temperatures (Larco, 2010). However, once the plants grow and shade the beds, extra water is no longer needed with weed mat.

Nitrogen fertilizers were applied by fertigation using a fertilizer injector (Dosatron International, Clearwater, FL) installed in the irrigation manifold. In 2012, the plants were fertigated with liquid ammonium sulfate $(9 \mathrm{~N}-0 \mathrm{P}-0 \mathrm{~K})$. That year, fertigation was initiated on 30 May and included four applications of $28 \mathrm{~kg} \cdot \mathrm{ha}^{-1} \mathrm{~N}$ every 2 weeks. The first two applications were injected at $2 \%$ by volume, but this concentration resulted in $\mathrm{N}$ deficiency (yellowing leaves) in the plants irrigated with wide drip lines because the roots in those plots were located too far from this relatively immobile $\mathrm{N}$ source. Therefore, the next two applications were reduced to $0.5 \%$ by volume, to slow the injection rate and potentially move more $\mathrm{N}$ and water through the soil during each fertigation event. The following year, the plants were fertigated with liquid urea $(20 \mathrm{~N}-0 \mathrm{P}-0 \mathrm{~K})$. Urea is much more mobile during fertigation than $\mathrm{NH}_{4}-\mathrm{N}$ but readily converts to $\mathrm{NH}_{4}$ within a few days after application (Haynes, 1990). The fertilizer was injected 10 times between $17 \mathrm{Apr}$. and 17 July at a rate of $18 \mathrm{~kg} \cdot \mathrm{ha}^{-1} \mathrm{~N}$ per application ( $1 \%$ by volume). There were no visual symptoms of $\mathrm{N}$ deficiency in the plants in 2013.

Measurements. Soil samples were collected for nutrient analysis using a 2-cmdiameter core sampler. The sampler was inserted $15-\mathrm{cm}$ deep at six random locations near the center of the bed in each treatment plot in June 2012 and July 2013. Each set of samples was pooled, air-dried, ground, homogenized, and analyzed for soil $\mathrm{pH}$ [ 1 soil: 1 water $(\mathrm{v} / \mathrm{v})]$ and Mehlich III extractable cations at a commercial laboratory (Brookside Laboratories, New Bremen, $\mathrm{OH})$. Leaves were also collected for nutrient analysis in early August each year. Four recently matured leaves were sampled from the center four plants in each plot, pooled, oven-dried at $70{ }^{\circ} \mathrm{C}$, ground, and analyzed for $\mathrm{N}$ using a combustion analyzer (Model CNS-2000; LECO Corp., St. Joseph, MI) and for P, K, $\mathrm{Ca}, \mathrm{Mg}$, and $\mathrm{S}$ using an inductively coupled plasma optical emission spectrometer (Optima 3000DV; PerkinElmer, Wellesley, MA) after microwave digestion in $70 \%(\mathrm{v} / \mathrm{v})$ nitric acid (Gavlak et al., 2005).
Soil water content was measured in each plot on 12 July and 7 Aug. 2013 using the Trase I time domain reflectometry system (Soilmoisture Equipment Corp., Santa Barbara, CA). The system was equipped with a $15-\mathrm{cm}$ waveguide. The waveguide was inserted

vertically into the soil at three locations in each treatment plot. Each measurement was taken between plants in the center of the bed within $1-2 \mathrm{~h}$ after an irrigation event.

Hyphal growth of $P$. cinnamomi was measured in a subset of the sawdust and

Table 2. Effects of mulch type, drip line placement, and gypsum amendment on shoot and root dry weight of 'Draper' blueberry grown for 2 years (2012-13) in a field infested by Phytophthora cinnamomi in Corvallis, OR. ${ }^{\mathrm{C}}$

\begin{tabular}{|c|c|c|c|c|c|}
\hline \multirow[b]{2}{*}{ Treatment } & \multicolumn{3}{|c|}{ Shoot dry wt (g/plant) } & \multicolumn{2}{|c|}{ Root dry wt (g/plant) } \\
\hline & 2012 & \multicolumn{2}{|c|}{2013} & 2012 & 2013 \\
\hline \multicolumn{6}{|l|}{$\overline{\text { Mulch }}$} \\
\hline Sawdust & 96 & \multicolumn{2}{|c|}{106} & 43 & 36 \\
\hline Weed mat & 86 & \multicolumn{2}{|c|}{85} & 45 & 41 \\
\hline Significance & NS & \multicolumn{2}{|c|}{ NS } & NS & NS \\
\hline \multicolumn{6}{|l|}{ Drip lines (D) } \\
\hline Narrow & 121 & \multicolumn{2}{|c|}{87} & 39 & 26 \\
\hline Wide & 61 & \multicolumn{2}{|c|}{105} & 49 & 51 \\
\hline Significance & $* * *$ & \multicolumn{2}{|c|}{ NS } & $*$ & $* * *$ \\
\hline Gypsum (G) & & Narrow & Wide & & \\
\hline No & 84 & $78 \mathrm{~b}^{\mathrm{y}}$ & $70 \mathrm{~b}$ & 43 & 33 \\
\hline Yes & 98 & $96 \mathrm{~b}$ & $139 \mathrm{a}$ & 46 & 44 \\
\hline Significance & NS & \multicolumn{2}{|c|}{$\mathrm{D} \times \mathrm{G}^{* *}$} & NS & NS \\
\hline
\end{tabular}

NS, ${ }^{*}, * *{ }^{* * *}$ Nonsignificant or significant at $P \leq 0.05,0.01$, and 0.001 , respectively.

${ }^{\mathrm{z}}$ The plants were harvested destructively in December of each year.

${ }^{\mathrm{y}}$ Means followed by the same letter are not significantly different $(P \leq 0.05)$.

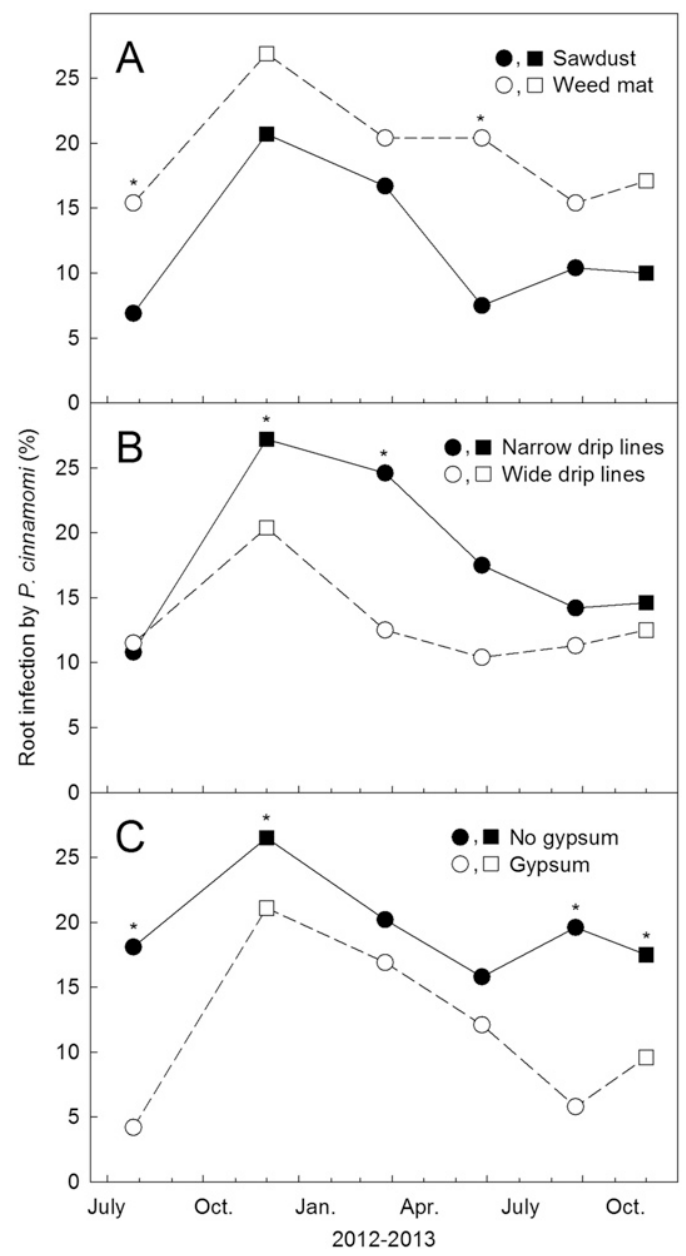

Fig. 1. Effects of mulch type (A), drip line placement $(\mathbf{B})$, and gypsum amendment $(\mathbf{C})$ on root infection incidence (\%) in 'Draper' blueberry grown for 2 years $(2012-13)$ in a field infested by Phytophthora cinnamomi in Corvallis, OR. Roots were sampled from soil cores $(\mathbf{O}, \bigcirc)$ or from destructively harvested plants $(\mathbf{\square}, \square)$. An asterisk above the symbols on a given sampling date indicates the means are significantly different at $P \leq 0.05$. 
Table 3. Soil heat units and hyphal growth of Phytophthora cinnamomi grown in situ on potato dextrose agar in sealed petri plates buried 5-cm deep under sawdust and weed mat for 7-10 $\mathrm{d}$ in a field of 'Draper' blueberry in Corvallis, OR.

\begin{tabular}{|c|c|c|c|c|c|c|}
\hline \multirow[b]{3}{*}{ Mulch } & \multicolumn{3}{|c|}{ Soil heat units $\left({ }^{\circ} \mathrm{C}\right)^{\mathrm{z}}$} & \multicolumn{3}{|c|}{ P. cinnamomi hyphal growth $\left(\mathrm{cm}^{2}\right)^{\mathrm{y}}$} \\
\hline & $9-16$ & $18-28$ & $11-19$ & $9-16$ & $18-28$ & $11-19$ \\
\hline & Aug. 2012 & Apr. 2013 & July 2013 & Aug. 2012 & Apr. 2013 & July 2013 \\
\hline Sawdust & 97 & 52 & 114 & 29.8 & 5.4 & 25.9 \\
\hline Weed mat & 112 & 64 & 118 & 37.1 & 7.3 & 28.3 \\
\hline Significance & $* * *$ & $* * *$ & $*$ & $* * *$ & ** & $*$ \\
\hline
\end{tabular}

${ }^{*, * *},{ }^{* * *}$ Significant at $P \leq 0.05,0.01$, and 0.001 , respectively.

${ }^{\mathrm{z}}$ Calculated at a baseline of $9{ }^{\circ} \mathrm{C}$ (Zentmyer et al., 1976).

${ }^{\mathrm{y}}$ Grown in situ on petri plates buried $5-\mathrm{cm}$ deep.

Table 4. Effects of mulch type, drip line placement, and gypsum amendment on soil water content in a field of 'Draper' blueberry infested by Phytophthora cinnamomi in Corvallis, OR. ${ }^{\text {' }}$

\begin{tabular}{|c|c|c|}
\hline \multirow[b]{2}{*}{ Treatment } & \multicolumn{2}{|c|}{ Soil water content $(\%)$} \\
\hline & July 2013 & Aug. 2013 \\
\hline \multicolumn{3}{|l|}{ Mulch } \\
\hline Sawdust & 31.5 & 19.1 \\
\hline Weed mat & 29.5 & 17.6 \\
\hline Significance & NS & NS \\
\hline \multicolumn{3}{|l|}{ Drip lines (D) } \\
\hline Narrow & 36.4 & 22.9 \\
\hline Wide & 24.5 & 13.8 \\
\hline Significance & $* * *$ & $* * *$ \\
\hline \multicolumn{3}{|l|}{ Gypsum (G) } \\
\hline No & 31.2 & 18.8 \\
\hline Yes & 29.8 & 17.9 \\
\hline Significance & NS & NS \\
\hline
\end{tabular}

weed mat plots. Single, 5-mm-diameter plugs of inoculum from the same isolate used to infest the field were aseptically transferred to new PDA petri plates under sterile conditions. The plates were wrapped with parafilm and placed in sealable plastic bags in two stacks of three per bag. The bags were buried 5 -cm deep in three subplots of sawdust and weed mat with wide drip lines and no gypsum. The plates were buried on three separate dates, including 9 Aug. 2012, 18 Apr. 2013, and 11 July 2013. The plates were recovered 7-10 d after burial, and the diameter of each culture was measured to the nearest millimeter in two perpendicular directions. Soil temperature was also recorded next to the buried bags using waterproof temperature loggers (HOBO Pendant; Onset Computer Corporation, Bourne, MA). The readings were taken every $15 \mathrm{~min}$, and heat units were calculated based on a minimum threshold of $9{ }^{\circ} \mathrm{C}$ (Zentmyer et al., 1976).

Root samples were collected from plots and assessed for infection for the eight cultural treatments on 26 July 2012 and on 25 Mar., 26 June, and 24 Sept. in 2013. The roots were removed by driving a $2-\mathrm{cm}$ diameter core sampler diagonally through the root zone of one plant/plot to a depth of $15 \mathrm{~cm}$. Twenty (2012) or 10 (2013) $1-\mathrm{cm}$ long root pieces were randomly sampled from the cores, rinsed in $1 \%$ bleach solution $(0.05 \% \mathrm{NaOCl})$ for $30 \mathrm{~s}$, and placed onto petri plates filled with $\mathrm{P}_{10} \mathrm{ARPH}$ agar. The agar is a semiselective medium for Phytophthora species (Tsao and Guy, 1977) and contained $10 \mathrm{ppm}$ pimaricin (SigmaAldrich, St. Louis, MO), 250 ppm ampicillin (Sigma-Aldrich), 10 ppm rifampicin (SigmaAldrich), $100 \mathrm{ppm}$ pentachloronitrobenzene (Terrachlor, $75 \%$ a.i.; Chemtura, Middlebury, CT), and 25 ppm hymexazol (Tachigaren, $70 \%$ a.i.; Sankyo Co., Tokyo). The plates were incubated at $20{ }^{\circ} \mathrm{C}$ for $10 \mathrm{~d}$ and monitored periodically under a microscope $(\times 400)$ to determine the percentage of the root sections infected by $P$. cinnamomi.

One plant from each treatment plot, including the fungicide controls, was harvested destructively in Dec. 2012 and 2013. The plants were selected randomly from either the north or south end of the plot and assessed for root infection following the same laboratory procedures mentioned above. In this case, the roots were washed with running tap water before collecting the 10 or 20 root pieces. Afterward, the plants were divided into root and shoots, oven-dried, and weighed.

Statistical analyses. Shoot and root dry weights, percent root infection, soil water content, soil $\mathrm{pH}$, and soil and leaf nutrient concentrations were analyzed by mixed model analysis of variance using the PROC MIXED statement in SAS 9.2 (SAS Institute, Cary, NC). To homogenize the variances before analysis, percent root infection was transformed using arcsine of the square root of the proportion. Fixed effects in the model included mulch type, drip line spacing, gypsum amendment, and each interaction among the eight cultural treatments. Random effects included bed and bed $\times$ mulch interaction to account for the split-plot experimental design. The fungicide treatment was not included in this analysis as it was not a component of the $2 \times 2 \times 2$ factorial design for comparing cultural effects. When interaction effects of the $2 \times 2 \times 2$ factorial design were significant, Tukey's HSD test was performed for multiple comparisons between means using the LSMEANS statement in PROC PLM, using the saved model context from the PROC MIXED analysis.

To evaluate the effect of fungicide, Tukey's HSD test was performed using the LSMEANS statement in PROC MIXED, comparing the fungicide control treatment (in sawdust mulch with narrow drip line and no gypsum amendment) with the treatment with the same combination of cultural factors, but no fungicide. The model included treatment as a fixed effect and bed as a random effect $(P \leq 0.05)$.

\section{Results and Discussion}

\section{Efficacy of the fungicides}

The plants treated with mefenoxam and fosetyl-Al were larger and produced more shoot and root dry weight than in comparable treatment plots (sawdust mulch, narrow drip lines, and no gypsum amendment) without the fungicides (Table 1). However, the percentage of the roots that were infected by $P$. cinnamomi in December was similar between the treatments during both years of the study. It is likely that there was little residual activity of either fungicide in Dec. 2012, $\approx 7$ months after the fungicides were applied in late May. Mefenoxam has a half-life of $\leq 70 \mathrm{~d}$ and, unless applied on a regular basis, does not have extended residual activity against $P$. cinnamomi (Benson, 1987). Fosetyl-Al was even less effective than mefenoxam in reducing root rot of azaleas inoculated with $P$. cinnamomi, leading Benson (1987) to conclude that fosetyl-Al had limited residual activity. Therefore, a better time to capture differences in root infection between the fungicide treatment and the cultural treatments would be within a month or two after fungicide application, when residual activity of each fungicide would have been greater.

\section{Response to the cultural practices}

Shoot and root dry weights. Among the cultural treatments, shoot and root dry weight were similar with sawdust and weed mat, but both were affected by drip line placement and the combination of gypsum and drip line placement each year (Table 2). Specifically, plants produced more shoot dry weight and less root dry weight with narrow drip lines than with wide drip lines in year 1. Vargas (2015) also examined the effects of drip line placement in northern highbush blueberry in the absence of Phytophthora and found that plant growth was generally greater when the drip lines were placed near the crown than at $20 \mathrm{~cm}$ on each side of the row during the first year after planting. The plants in the present study also had less root dry weight with narrow drip lines in year 2, but at this point, had the greatest shoot dry weight when they were treated with a combination of gypsum and wide drip lines.

Root infection. As predicted, the plants had more root infection with weed mat than with sawdust mulch, but only in June or July each year (Fig. 1A), or in Dec. 2013 in plots with weed mat and no gypsum (data not shown). Weed mat generally increased soil temperature relative to sawdust and resulted in more hyphal growth by the pathogen throughout the season (Table 3). Thus, it was somewhat surprising that plant growth was similar between the sawdust and weed mat treatments, as mentioned previously. Phytophthora cinnamomi is considered a warm-weather pathogen with optimal growth occurring at $24-28{ }^{\circ} \mathrm{C}$ (Erwin and Ribeiro, 1996). Our observations were reflective of this temperature dependence in which hyphal growth was four to five times greater in Aug. 
Table 5. Effects of mulch type, drip line placement, and gypsum amendment on soil pH and extractable cations in a field of 'Draper' blueberry infested by Phytophthora cinnamomi in Corvallis, OR. ${ }^{\mathrm{z}}$

\begin{tabular}{|c|c|c|c|c|c|c|c|c|c|c|c|}
\hline \multirow[b]{2}{*}{ Treatment } & \multicolumn{3}{|c|}{ Soil pH } & \multicolumn{3}{|c|}{ Soil Ca $(\mathrm{meq} / 100 \mathrm{~g})$} & \multicolumn{3}{|c|}{ Soil K (meq/100 g) } & \multicolumn{2}{|c|}{ Soil $\mathrm{Mg}(\mathrm{meq} / 100 \mathrm{~g})$} \\
\hline & \multicolumn{2}{|c|}{2012} & 2013 & 2012 & \multicolumn{2}{|c|}{2013} & 2012 & \multicolumn{2}{|c|}{2013} & 2012 & 2013 \\
\hline \multicolumn{12}{|l|}{ Mulch (M) } \\
\hline Sawdust & \multicolumn{2}{|c|}{4.6} & 5.1 & 15.9 & \multicolumn{2}{|c|}{12.2} & 0.52 & \multicolumn{2}{|c|}{0.44} & 5.0 & 5.9 \\
\hline Significance & \multicolumn{2}{|c|}{ NS } & NS & NS & \multicolumn{2}{|c|}{ NS } & NS & \multicolumn{2}{|c|}{ NS } & NS & NS \\
\hline Drip lines (D) & Sawdust & Weed mat & & & & & & Sawdust & Weed mat & & \\
\hline Narrow & $4.1 \mathrm{~b}^{\mathrm{y}}$ & $4.1 \mathrm{~b}$ & 4.9 & 14.8 & & & 0.47 & $0.36 \mathrm{~b}$ & $0.41 \mathrm{~b}$ & 4.9 & 5.8 \\
\hline Wide & $5.1 \mathrm{a}$ & $5.2 \mathrm{a}$ & 5.5 & 17.7 & & & 0.53 & $0.52 \mathrm{a}$ & $0.50 \mathrm{a}$ & 5.4 & 6.2 \\
\hline No & $4.1 \mathrm{c}$ & $5.3 \mathrm{a}$ & 5.4 & 9.8 & $10.1 \mathrm{c}^{\mathrm{y}}$ & $11.5 \mathrm{bc}$ & 0.50 & & & 5.6 & 6.4 \\
\hline Yes & $4.1 \mathrm{c}$ & $5.0 \mathrm{~b}$ & 5.1 & 22.6 & $11.6 \mathrm{~b}$ & $15.6 \mathrm{a}$ & 0.50 & & & 4.7 & 5.6 \\
\hline Significance & \multicolumn{2}{|c|}{$\mathrm{D} \times \mathrm{G}^{* * *}$} & $* * *$ & $* * *$ & \multicolumn{2}{|c|}{$\mathrm{D} \times \mathrm{G}^{* *}$} & NS & & & $* * *$ & $* * *$ \\
\hline Recommended range $^{x}$ & \multicolumn{3}{|c|}{$4.5-5.5$} & \multicolumn{3}{|c|}{ N/A } & \multicolumn{3}{|c|}{$>0.38$} & \multicolumn{2}{|c|}{ N/A } \\
\hline
\end{tabular}

$\mathrm{N} / \mathrm{A}=$ not available.

NS, *,**,*** Nonsignificant or significant at $P \leq 0.05,0.01$, and 0.001 , respectively.

${ }^{\mathrm{z}}$ Measurements were taken at a soil depth of $0-15 \mathrm{~cm}$.

${ }^{\mathrm{y}}$ Means followed by the same letter are not significantly different $(P \leq 0.05)$.

${ }^{\mathrm{x}}$ From Hart et al. (2006).

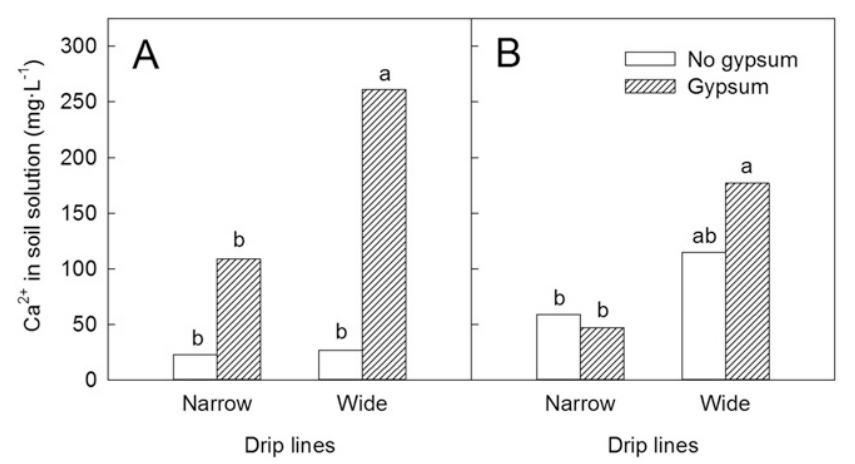

Fig. 2. Effects of the interaction between drip line placement and gypsum amendment on $\mathrm{Ca}^{2+}$ concentration in the soil solution at (A) 5 months (Oct. 2012) and (B) 16 months (Sept. 2013) after the treatments were initiated in a field of 'Draper' blueberry infested by Phytophthora cinnamomi in Corvallis, OR. Means with the same letter are not significantly different at each sampling date $(P \leq 0.05)$.

2012 and July 2013 than in Apr. 2013 (Table 3). Based on readings at the AgriMet weather station, average maximum soil temperatures at 10 - to 20 -cm depth (without mulch) were consistently $\geq 24{ }^{\circ} \mathrm{C}$ during June through September. Thus, the most likely time of year to observe differences between the two mulch types would be during the summer (Fig. 1A; Table 3), when soil temperatures would reach the optimal hyphal growth temperature more often and for longer periods under weed mat than under sawdust. During the rest of the year, soil temperatures are usually less than the optimal temperature for hyphal growth and frequently drop below the minimum growth threshold of $5-6^{\circ} \mathrm{C}$. Our data show that root infection incidence was similar under sawdust and weed mat during the cooler months (Fig. 1A).

The plants also had more root infection at times with narrow drip lines than with wide drip lines (Fig. 1B), but less infection with gypsum, particularly during the latter months of the season each year (Fig. 1C). Soil water content was greater with the narrow drip lines (Table 4) and, regardless of mulch type or gypsum application, likely increased the activity of the pathogen (de Silva et al.,
1999). Similar results were found in a previous study on 'Duke' blueberry at this site (Bryla, 2006). Calcium ions from the gypsum, in contrast to increased water content, likely inhibited the pathogen (Byrt et al., 1982; von Broembsen and Deacon, 1997).

Soil $\mathrm{pH}$ and extractable cations. Soil $\mathrm{pH}$ and extractable cations were largely unaffected by mulch type each year, but each was often greater near plants with wide drip lines than those with narrow drip lines (Table 5). In general, soil $\mathrm{pH}$ decreased after planting, which was likely due to nitrification of $\mathrm{NH}_{4}-\mathrm{N}$ from the fertilizers (Bryla and Strik, 2015). Only a fraction of the $\mathrm{NH}_{4}-\mathrm{N}$ applied to a field of blueberry is taken up by the plants; the remainder is converted to $\mathrm{NO}_{3}-\mathrm{N}$ via nitrification by soil bacteria (Bañados et al., 2012). The process results in the release of $\mathrm{H}^{+}$ions, thereby increasing soil acidity. Presumably, $\mathrm{NH}_{4}-\mathrm{N}$ was more concentrated near plants with narrow drip lines, thus reducing $\mathrm{pH}$ to a greater extent than with wide drip lines.

The addition of gypsum increased the concentration of extractable $\mathrm{Ca}$ in both the soil and the soil solution each year (Table 5; Fig. 2). In both cases, Ca levels decreased over time and, by the second or third year, were only greater when gypsum was applied in combination with wide drip lines. Apparently, $\mathrm{Ca}^{2+}$ ions, which move primarily by mass flow in the soil (Barber, 1995), were more concentrated beneath the plants with wide drip lines and, over time, leached below the root zone. Most of the roots were located $<0.3$-m deep in each plot (data not shown), which is typical for blueberry (Bryla and Strik, 2007).

With the exception of plots with narrow drip lines in the first year, gypsum reduced soil $\mathrm{pH}$ by 0.3 units (Table 5). Usually, gypsum application has little effect on soil pH in nonsodic soils (Shainberg et al., 1989). However, others have reported a slight decrease in the $\mathrm{pH}$ of acidic soils after application of gypsum, which was attributed to the salt effect of the $\mathrm{Ca}^{2+}$ exchanging $\mathrm{H}^{+}$and $\mathrm{Al}^{-}$ ions from soil colloids into the soil solution (O'Brien and Sumner, 1988; Takahashi et al., 2006; Toma et al., 1999).

Gypsum also reduced the amount of extractable $\mathrm{Mg}$ by nearly $1 \mathrm{meq} / 100 \mathrm{~g}$ soil each year (Table 5). Likely, $\mathrm{Mg}$ was replaced by $\mathrm{Ca}$ from the gypsum and consequently leached to lower depths in the soil (Toma et al., 1999). Because this commonly happens, Sumner (1993) suggested applying Mg fertilizer following a gypsum application to maintain adequate levels of $\mathrm{Mg}$ in the soil.

Foliar nutrients. The concentration of most of the important nutrients in the leaves, including $\mathrm{P}, \mathrm{K}, \mathrm{Mg}, \mathrm{S}$, and, in all but one case, $\mathrm{Ca}$, was within or above the range recommended for northern highbush blueberry; however, leaf $\mathrm{N}$ concentration was often below the range, particularly in treatments with wide drip lines (Table 6). As mentioned, the plants were fertigated initially with $\mathrm{NH}_{4}$ $\mathrm{N}$ source, which moves very slowly in the soil. Because young blueberry plants have small root systems, much of the $\mathrm{N}$ that was applied with wide drip lines in the first year probably never reached the roots before it was converted to $\mathrm{NO}_{3}-\mathrm{N}$ (Bryla and Strik, 2015). To compensate, the plants would need to be either fertigated with a mobile source of $\mathrm{N}$, such as urea, or fertilized near the crown 
Table 6. Effects of mulch type, drip line placement, and gypsum amendment on the concentration of foliar nutrients in 'Draper' blueberry grown for 2 years (2012-13) in a field infested by Phytophthora cinnamomi in Corvallis, OR.

\begin{tabular}{|c|c|c|c|c|c|c|c|c|c|c|c|c|c|c|c|}
\hline \multirow[b]{2}{*}{ Treatment } & \multicolumn{2}{|c|}{ Foliar N (\%) } & \multicolumn{3}{|c|}{ Foliar P (\%) } & \multicolumn{2}{|c|}{ Foliar K (\%) } & \multicolumn{3}{|c|}{ Foliar $\mathrm{Ca}(\%)$} & \multicolumn{3}{|c|}{ Foliar Mg (\%) } & \multicolumn{2}{|l|}{ Foliar S (\%) } \\
\hline & 2012 & 2013 & & 012 & 2013 & 2012 & 2013 & & $\longdiv { 1 2 }$ & 2013 & & 12 & 2013 & 2012 & 2013 \\
\hline Sawdust & 1.35 & 1.89 & & .10 & 0.10 & 0.53 & 0.47 & & 55 & 0.48 & \multicolumn{2}{|c|}{0.17} & 0.19 & 0.28 & 0.12 \\
\hline Drip lines (D) & & & \multicolumn{5}{|c|}{ Sawdust Weed mat } & Sawdust & Weed mat & & \multicolumn{5}{|c|}{ Sawdust Weed mat } \\
\hline Narrow & 1.69 & 2.04 & $0.10 \mathrm{a}^{\mathrm{z}}$ & $0.10 \mathrm{a}$ & 0.10 & 0.48 & 0.47 & $0.53 \mathrm{ab}$ & $0.56 \mathrm{ab}$ & 0.46 & $0.16 \mathrm{~b}$ & $0.17 \mathrm{ab}$ & 0.19 & 0.26 & 0.12 \\
\hline Wide & 0.94 & 1.45 & $0.10 \mathrm{a}$ & $0.08 \mathrm{~b}$ & 0.10 & 0.54 & 0.53 & $0.57 \mathrm{a}$ & $0.52 \mathrm{~b}$ & 0.44 & $0.18 \mathrm{a}$ & $0.17 \mathrm{ab}$ & 0.17 & 0.25 & 0.12 \\
\hline No & 1.30 & $2.03 \mathrm{a} \quad 1.35 \mathrm{c}$ & & .10 & 0.10 & 0.46 & 0.46 & $0.53 \mathrm{bc}$ & $0.50 \mathrm{c}$ & 0.38 & $0.17 \mathrm{~b}$ & $0.16 \mathrm{~b}$ & 0.18 & $0.23 \mathrm{c} \quad 0.15 \mathrm{~d}$ & 0.10 \\
\hline Yes & 1.33 & $2.05 \mathrm{a} \quad 1.56 \mathrm{~b}$ & & .10 & 0.11 & 0.57 & 0.53 & $0.55 \mathrm{ab}$ & $0.60 \mathrm{a}$ & 0.52 & $0.17 \mathrm{~b}$ & $0.19 \mathrm{a}$ & 0.18 & $0.28 \mathrm{~b} \quad 0.34 \mathrm{a}$ & 0.13 \\
\hline Significance & NS & $\mathrm{D} \times \mathrm{G}^{*}$ & & NS & NS & $\mathrm{M} \times \mathrm{D} \times \mathrm{G}^{*}$ & NS & $\mathrm{D} \times$ & $\mathrm{G}^{* *}$ & * & $\mathrm{D} \times$ & $\mathrm{G}^{* * *}$ & NS & $\mathrm{D} \times \mathrm{G}^{* * *}$ & $* * *$ \\
\hline $\begin{array}{l}\text { Recommended } \\
\text { range }^{y}\end{array}$ & & $1.76-2.00$ & & $>0.07$ & & $0.41-0$ & & & $41-0.80$ & & & $.13-0.25$ & & $0.11-0.16$ & \\
\hline
\end{tabular}

NS, ${ }^{*}, * *, * * *$ Nonsignificant or significant at $P \leq 0.05,0.01$, and 0.001 , respectively.

${ }^{\mathrm{z}}$ Means followed by the same letter are not significantly different $(P \leq 0.05)$.

${ }^{\mathrm{y}}$ Recommendations are from Strik and Vance (2015).

with a granular $\mathrm{N}$ product. Liquid urea was indeed more effective in the second year than liquid ammonium sulfate was in the first year, but leaf $\mathrm{N}$ continued to remain below the recommended range in the treatments with wide drip lines. Vargas (2015) tried spreading small doses of granular urea around the plants before fertigating with wide drip lines; the treatment resulted in greater leaf $\mathrm{N}$ than fertigation only, but it did not improve plant growth. More research is needed to develop a suitable method for providing adequate $\mathrm{N}$ with wide drip lines during plant establishment.

By the second year, the concentration of $\mathrm{Ca}$ in the leaves was slightly below the recommended range in plants grown in plots without gypsum (Table 6). Apparently, soil $\mathrm{Ca}$ was insufficient at the site unless gypsum was applied. Low soil $\mathrm{pH}$ can sometimes lead to low leaf $\mathrm{Ca}$ concentrations in blueberry (Hart et al., 2006). However, the soil pH was always near or within the desired range in each treatment (Table 5). When foliar $\mathrm{Ca}$ is low, Hart et al. (2006) recommend applying $1-2 \mathrm{t} \cdot \mathrm{ha}^{-1}$ of lime if the soil $\mathrm{pH}$ is $<4$ and $1-2$ t.ha ${ }^{-1}$ of gypsum if the $\mathrm{pH}$ is $>5$. A slightly greater rate of gypsum $\left(2.24 \mathrm{t} \cdot \mathrm{ha}^{-1}\right)$ was applied in the present study. Adding gypsum increased the concentration of both $\mathrm{Ca}$ and $\mathrm{S}$ in the leaves, particularly with wide drip lines in the first year. These ions are mobile in the soil and often become concentrated in the root zone with wide drip lines (Mmolawa and Or, 2000). Leaf Ca and S concentrations were also affected by mulch type in the first year. That year, foliar $\mathrm{Ca}$ was greater with sawdust than with weed mat when the plants were irrigated with wide drip lines, whereas leaf S was greater with sawdust than with weed mat regardless of the drip lines.

Mulch type, drip placement, and gypsum also affected the concentration of other nutrients in the leaves during the first growing season (Table 6). Foliar P, for example, was lower with wide drip lines than with narrow drip lines, but only when the plants were mulched with weed mat. Foliar K, on the other hand, was greater with sawdust mulch, wide drip lines, and gypsum, on average, and the additive combination of each resulted in the highest concentration of foliar K (i.e., $0.66 \%$ ) among the treatments. Finally, foliar $\mathrm{Mg}$ was greater with wide drip lines than with narrow lines under sawdust and was also greater with the combination of wide drip lines and gypsum than with narrow drip lines or no gypsum. Although the cause of the observed treatment effects on foliar P levels is unclear, Vargas (2015) found that $\mathrm{K}$ and $\mathrm{Mg}$ moved with the wetting front and concentrated near the plants irrigated with wide drip lines.

\section{Conclusions}

Based on the results of this study, it appears that gypsum and wide drip lines are effective at suppressing phytophthora root rot in northern highbush blueberry. Together, these practices resulted in the largest plants among the cultural treatments but still did not increase plant growth to levels similar to those obtained with fungicides. However, plant growth was limited during the first year with the treatments, primarily as a result of $\mathrm{N}$ deficiency with the wide drip lines. Research is underway to identify a method to correct the problem.

Weed mat increased root infection by $P$. cinnamomi relative to sawdust and resulted in warmer soil conditions and greater hyphal growth. Although plant growth was not adversely affected after 2 years with weed mat, caution is warranted when using weed mat with susceptible cultivars (Yeo et al., 2016) and at sites conducive to phytophthora root rot (e.g., heavy soils and poor drainage).

\section{Literature Cited}

Bañados, M.P., B.C. Strik, D.R. Bryla, and T.L. Righetti. 2012. Response of highbush blueberry to nitrogen fertilizer during field establishment. I: Accumulation and allocation of fertilizer nitrogen and biomass. HortScience 47:648-655.

Barber, S.A. 1995. Soil nutrient bioavailability. 2nd ed. Wiley, New York, NY.
Benson, D.M. 1987. Residual activity of metalaxyl and population dynamics of Phytophthora cinnamomi in landscape beds of azalea. Plant Dis. 71:886-891.

Brannen, P.M., P. Harmon, and D.S. NeSmith. 2009. Utility of phosphonate fungicides for management of phytophthora root rot of blueberry. Acta Hort. 810:331-340.

Bryla, D.R. 2006. Drip irrigation configuration influences growth in young highbush blueberries. HortScience 41:1012 (abstr.).

Bryla, D.R. and R.G. Linderman. 2007. Implications of irrigation method and amount of water application on Phytophthora and Pythium infection and severity of root rot in highbush blueberry. HortScience 42:1463-1467.

Bryla, D.R. and B.C. Strik. 2007. Effects of cultivar and plant spacing on the seasonal water requirements of highbush blueberry. J. Amer. Soc. Hort. Sci. 132:270-277.

Bryla, D.R. and B.C. Strik. 2015. Nutrient requirements, leaf tissue standards, and new options for fertigation of northern highbush blueberry. HortTechnology 25:464-470.

Bryla, D.R., J.L. Gartung, and B.C. Strik. 2011. Evaluation of irrigation methods for highbush blueberry-I. Growth and water requirements of young plants. HortScience 46:95-101.

Byrt, P.N., H.R. Irving, and B.R. Grant. 1982. The effect of cations on zoospores of the fungus Phytophthora cinnamomi. J. Gen. Microbiol. 128:1189-1198.

de Silva, A., K. Patterson, C. Rothrock, and R. Mc New. 1999. Phytophthora root rot of blueberry increases with frequency of flooding. HortScience 34:693-695.

DeVetter, L.W., D. Granatstein, E. Kirby, and M. Brady. 2015. Opportunities and challenges of organic highbush blueberry production in Washington State. HortTechnology 25:796804.

Downer, A.J., J.A. Menge, and E. Pond. 2001. Association of cellulytic enzyme activities in Eucalyptus mulches with biological control of Phytophthora cinnamomi. Phytopathology 91:847-855.

Ehret, D.L., B. Frey, T. Forge, T. Helmer, and D.R. Bryla. 2012. Effects of drip irrigation configuration and rate on yield and fruit quality of young highbush blueberry plants. HortScience 47:414-421.

Erwin, D.C. and O.K. Ribeiro. 1996. Phytophthora diseases worldwide. APS Press, St. Paul, MN. 
Gavlak, R.G., D.A. Horneck, and R.O. Miller. 2005. The soil, plant and water reference methods for the western region, 2005. 3rd ed. Western Regional Ext. Publ. 125. Univ. Alaska, Fairbanks, AK.

Hart, J., B. Strik, L. White, and W. Yang. 2006. Nutrient management for blueberries in Oregon. Oregon State Univ. Ext. Pub. EM 8918.

Haynes, R.J. 1990. Movement and transformations of fertigated nitrogen below trickle emitters and their effects on $\mathrm{pH}$ in the wetted soil volume. Nutr. Cycl. Agroecosyst. 23:105-112.

Hu, J., C. Hong, E.L. Stromberg, and G.W. Moorman. 2010. Mefenoxam sensitivity in Phytophthora cinnamomi isolates. Plant Dis. 94:39-44.

Julian, J.W., B.C. Strik, H.O. Larco, D.R. Bryla, and D.M. Sullivan. 2012. Cost of establishing organic northern highbush blueberry: Impacts of planting method, fertilization, and much type. HortScience 47:866-873.

Larco, H.O. 2010. Effect of planting method, weed management, and fertilizer on plant growth and yield of newly established organic highbush blueberries. Oregon State Univ., Corvallis, OR, MS Diss. <http://ir.library.oregonstate.edu/ xmlui/handle/1957/18065>.

Larco, H., B.C. Strik, D.R. Bryla, and D.M. Sullivan. 2013. Mulch and fertilizer management practices for organic production of highbush blueberry. I: Plant growth and allocation of biomass during establishment. HortScience 48:1250-1261.

Menge, J.A., H.D. Ohr, E.L.V. Johnson, S. Campbell, F. Guillemet, N. Grech, and E. Pond. 1994. The effect of mulches, gypsum and fungicides on the performance of avocado planted in soil with Phytophthora cinnamomi and Phytophthora citricola. Phytopathology 84:1103 (abstr.).

Messenger, B.J., J.A. Menge, and E. Pond. 2000a. Effects of gypsum soil amendments on avocado growth, soil drainage, and resistance to Phytophthora cinnamomi. Plant Dis. 84:612-616.
Messenger, B.J., J.A. Menge, and E. Pond. 2000b. Effects of gypsum on zoospores and sporangia of Phytophthora cinnamomi in field soil. Plant Dis. 84:617-621.

Mmolawa, K. and D. Or. 2000. Root zone solute dynamics under drip irrigation: A review. Plant Soil 222:163-190.

O’Brien, L.O. and M.E. Sumner. 1988. Effects of phosphogypsum on leachate and soil chemical composition. Commun. Soil Sci. Plant Anal. 19:1319-1329.

Pinkerton, J.N., P.R. Bristow, G.E. Windom, and T.W. Walters. 2009. Soil solarization as a component of an integrated program for control of raspberry root rot. Plant Dis. 93:452-458.

Richter, B.S., D.M. Benson, and K.L. Ivors. $2011 \mathrm{a}$. Microbial profiling of cultural systems for suppression of phytophthora root rot in Fraser fir. Plant Dis. 95:537-546.

Richter, B.S., K. Ivors, W. Shi, and D.M. Benson. 2011b. Cellulase activity as a mechanism for suppression of phytophthora root rot in mulches. Phytopathology 101:223-230.

Shainberg, I., M.E. Sumner, W.P. Miller, M.P.W. Farina, M.A. Pavan, and M.V. Fey. 1989. Use of gypsum on soils: A review. Adv. Soil Sci. 9:1-111.

Strik, B.C. and D. Yarborough. 2005. Blueberry production trends in North America, 1992 to 2003 and predictions for growth. HortTechnology 15:391-398.

Strik, B.C. and A. Vance. 2015. Seasonal variation in leaf nutrient concentration of northern highbush blueberry cultivars grown in conventional and organic production systems. HortScience 50:1453-1466.

Sumner, M.E. 1993. Gypsum and acid soils: The world scene. Adv. Agron. 51:1-32.

Takahashi, T., Y. Ikeda, H. Nakamura, and M. Nanzyo. 2006. Efficiency of gypsum application to acid Andosols estimated using aluminum release rates and plant root growth. Soil Sci. Plant Nutr. 52:584-592.
Toma, M., M.E. Sumner, G. Weeks, and M. Saigusa. 1999. Long-term effects of gypsum on crop yield and subsoil chemical properties. Soil Sci. Soc. Amer. J. 39:891-895.

Tsao, P.H. and S.O. Guy. 1977. Inhibition of Mortierella and Pythium in a Phytophthora isolation medium containing hymexazol. Phytopathology 67:796-801.

Vargas, O.L. 2015. Nitrogen fertigation practices to optimize growth and yield of highbush blueberry (Vaccinium corymbosum L.). Oregon State Univ., Corvallis, OR, PhD Diss. <https:// ir.library.oregonstate.edu/xmlui/handle/1957/ $55644>$.

Vargas, O.L., D.R. Bryla, J.E. Weiland, B.C. Strik, and L. Sunday. 2015. Irrigation and fertigation with drip and alternative micro irrigation systems in northern highbush blueberry. HortScience 50:897-903.

von Broembsen, S.L. and J.W. Deacon. 1997. Calcium interference with zoospore biology and infectivity of Phytophthora parasitica in nutrient irrigation solutions. Phytopathology 87 : 522-528.

Yeo, J.R. 2014. Cultural controls for suppressing Phytophthora cinnamomi root rot of blueberry. Oregon State Univ., Corvallis, OR, PhD Diss. $<$ https://ir.library.oregonstate.edu/xmlui/handle/ $1957 / 53338>$.

Yeo, J.R., J.E. Weiland, D.M. Sullivan, and D.R. Bryla. 2016. Susceptibility of highbush blueberry cultivars to phytophthora root rot. HortScience 51:74-78.

Zentmyer, G.A. 1980. Phytophthora cinnamomi and the diseases it causes. Amer. Phytopathol. Soc. Monogr. Vol. 10. Amer. Phytopathol. Soc., St. Paul, MN.

Zentmyer, G.A., J.V. Leary, L.J. Klure, and G.L. Grantham. 1976. Variability in growth of Phytophthora cinnamomi in relation to temperature. Phytopathology 66:982-986. 